\title{
Comparative study on hematological parameters of farmed matrinxã, Brycon amazonicus Spix and Agassiz, 1829 (Characidae: Bryconinae) with others Bryconinae species
}

\author{
Marcos TAVARES-DIAS ${ }^{1}$, Elizabeth Gusmão AFFONSO², Sarah Ragonha OLIVEIRA², Jaydione Luiz \\ MARCON $^{3}$, Mizue Imoto EGAMI ${ }^{4}$
}

\begin{abstract}
The aim of this study was not only to determine the red blood cells parameters, thrombocyte and leukocyte counts in farmed Brycon amazonicus (matrinxã), to compare these parameters among Bryconinae species from literature, and also to investigate the presence of special granulocytic cells in these fish. The results of the blood cells parameters here established for farmed $B$. amazonicus, a species of great economic importance in Brazilian aquaculture, could help a better understanding of the blood features in natural populations of this Amazon species. Blood parameters varied between Bryconinae species investigated, mainly the red blood cell counts, hemoglobin, hematocrit and mean corpuscular volume (MCV). The presence of the blood granulocytes, neutrophils and heterophils in matrinxã suggest that both leukocytes can be a characteristic for Bryconinae family. Furthermore, it indicates that the existence of special granulocytic cells in the blood of Bryconinae species from literature is an artifact, and this was herein discussed.
\end{abstract}

KEYWORDS: Leukocytes, Freshwater fish, Blood, Amazon, Brycon amazonicus, Bryconinae,

\section{Estudo comparativo sobre parâmetros hematológicos de matrinxã Brycon amazonicus Spix e Agassiz, 1892(Characidae: Bryconinae) criados em cativeiro, com outras espécies de Bryconinae}

\section{RESUMO}

O objetivo deste estudo foi determinar os parâmetros eritrocíticos, as contagens de trombócitos e de leucócitos de espécimes de Brycon amazonicus (matrinxã), criados em cativeiro e compará-los com aqueles descritos na literatura para outras espécies de Bryconinae. Além disso, foi ainda investigada a presença de células granulocíticas especiais nestes peixes. Os resultados dos parâmetros sangüíneos apresentados para $B$. amazonicus podem ajudar a entender melhor as características sangüíneas em população natural desta espécie de grande importância para a aqüicultura brasileira. Os parâmetros sangüíneos das espécies de Bryconinae investigadas apresentaram variação interespecíficas principalmente a contagem de eritrócitos, hemoglobina, hematócrito e volume corpuscular médio (VCM). A presença dos granulócitos sangüíneos, neutrófilos e heterófilos em matrinxã sugere que esta pode ser uma característica das espécies pertencentes à subfamília Bryconinae. Além disso, indica que a existência de células granulocíticas especiais no sangue de espécies de Bryconinae da literatura é um artefato, e isto foi aqui discutido.

PALAVRAS-CHAVE: Leucócitos, peixe de água doce, sangue, Amazônia, Brycon amazonicus, Bryconinae.

${ }^{1}$ EMBRAPA AMAPÁ. Rod. Juscelino Kubitschek, km 5, №2600, Caixa Postal 10, Macapá, 68903-419, AP, Brasil. marcostavares@cpafap.embrapa.br

${ }^{2}$ Coordenação de Pesquisa em Aqüicultura (CPAQ), Instituto Nacional de Pesquisa da Amazônia (INPA), Manaus, Amazonas (Brasil). Avenida. André Araújo, 2936, Caixa Postal 478, Manaus, AM, 69069-001, Brasil.

${ }^{3}$ Departamento de Ciências Fisiológicas, Instituto de Ciências Biológicas, Universidade Federal do Amazonas. Avenida. Gal. Rodrigo Octávio Jordão Ramos, 3000. Coroado I, 69077-000. Manaus, AM, Brasil.

${ }^{4}$ Departamento de Morfologia, Universidade Federal da Escola de Medicina de São Paulo (UNIFESP). Rua Botucatu, 740. Ed. Lemos Torres, $2^{0}$ andar. Vila Clementina, São Paulo, SP, Brasil. 


\section{INTRODUCTION}

Some fish species of the Bryconinae subfamily and Characidae family are of great economic interest due to its fast growth and low mortality rates, good breeding performance and better resistance to parasitic diseases. Among these Bryconinae species is the matrinxã Brycon amazonicus Spix and Agassiz, 1829, which in recent review (Lima, 2003) regarding Bryconinae, this species has been reported to belong to Brazilian Amazon Rivers and Colombia, Venezuela and Guiana, in the basins from Orinoco and Essequibo Rivers. However, B. cephalus (=B. Siebenthalae) is found only in upper Amazon River basin in Peru and Bolivia, while the B. insignis is found in River Paraíba do Sul basin. Therefore, this important taxonomic review finished with a hindrance that hindered studies of comparison of blood features among Bryconinae species from literature.

Studies of blood parameters have been carried out to either determine the systematic relationship among certain species or for the knowledge of their physiology (Pavlidis et al., 2007). The hematological profile of a fish population could indicate its physiological status and health and in this way hematology combined with other routine diagnostic methods could be used to identify and assess conditions that cause stress to the fish and, consequently, disease (Tavares-Dias and Moraes, 2004; Tavares-Dias and Moraes, 2006a; Tavares-Dias and Moraes, 2007; Pavlidis et al., 2007). Red blood cell parameters can be used for the diagnosis of anemia while the leukocytes, the primary line of immunological defense, provide an important representation of defense cells throughout the body (Tavares-Dias and Moraes, 2004; Tavares-Dias and Moraes, 2007; Affonso et al., 2007; Pavlidis et al., 2007). Thus, one of the most elementary ways to assess the immune system is to explore changes in the number or appearance of fish circulating white blood cells (WBC).

Despite fish hematology continues to offer a potential valuable tool, the progress to establish blood parameters is slow and literature on this subject is isolated and often incomplete (Kori-Siakpere et al., 2005). Studies of blood parameters were carried out in some Bryconinae species such as Brycon sp. (Ranzani-Paiva, 1991; 1996), which can be the B. insignis (for more details, see Lima, 2003) besides Brycon hilarri (Tavares-Dias et al., 2003), B. amazonicus (Tavares-Dias et al., 1999, 2003; Affonso et al., 2007) and B. orbignyanus (Tavares-Dias and Moraes, 2006a). However, no comparison study for hematological parameters among Bryconinae species has been reported, until the present moment.

Piscine leukocytes, particularly granulocytes of Bryconinae, have been controversial. In Brycon insignis (Ranzani-Paiva, 1996) and B. amazonicus (Tavares-Dias et al., 1999) lymphocytes, monocytes, neutrophils, and an granulocyte known in the literature as a special granulocytic cells (SGC) or
PAS-positive granular leukocyte (PAS-GL) has been reported. In other studies regarding leukocytes of $B$. amazonicus (Carneiro et al., 2002; Tavares-Dias et al., 2003) were found only lymphocytes, monocytes and neutrophils, while in $B$. hilarri (Tavares-Dias et al., 2003) were found lymphocytes, monocytes, neutrophils and also eosinophils. In all these studies the granulocytes presented similar morphological features when stained with May Grünvald-Giemsa, a Romanowsky-type staining. However, in B. cephalus (Arévalo and Castellano, 2003) and B. orbignyanus (Tavares-Dias and Moraes, 2006a, b) besides lymphocytes, monocytes and neutrophils, heterophils also has been reported, but only $B$. cephalus presented blood eosinophils. Affonso et al. (2007) who investigated the physiological effects of the high vitamin C levels in the diet of B. amazonicus, also found lymphocytes, monocytes, neutrophils and heterophils stained with a combination of May Grünvald-Giemsa-Wright, another Romanowsky-type staining.

These studies indicate that despite of the ease determination of the leukocyte type this can be hampered by difficulties in classifying certain types of granulocytes. In the fish circulating blood besides mature cells there are also blastic cells and maturing cells of particular development lineages (TavaresDias and Moraes, 2004; Tavares-Dias and Barcellos 2005; Tavares-Dias, 2006; Tavares-Dias and Moraes, 2007). Thus, this inconsistency in cell nomenclature and appearance has lead to confusion regarding the identity of some cells in Bryconinae species. Therefore, this study was carried out to report hematological parameters of B. amazonicus in addition to compare them to others Bryconinae species from literature. Furthermore, it was investigated if the presence of special granulocytic cells in blood smears of this specie is a fact or artifact.

\section{MATERIALS AND METHODS}

\section{FISH MAINTENANCE AND EXPERIMENT}

Brycon amazonicus juveniles $(28.1 \pm 6.5 \mathrm{~g}$ and $13.0 \pm 1.4$ $\mathrm{cm})$, originating from the same spawning, were distributed in a $216 \mathrm{~m}^{2}$ excavated pond, at a stocking rate of $1 \mathrm{fish} / \mathrm{m}^{2}$, at the Aquaculture Department/INPA, AM, Brazil. The fish were fed with pelleted diets containing $28 \%$ crude protein. After 82 days-old, blood samples were collected from 25 fish in order to investigate the hematological parameters.

Water quality was daily monitored throughout the experiment. During the experiment, fish were observed for any clinical signs of diseases, including lack of appetite, increased opercular movements or visible lesions on the skin, tail and fins. Thus, no fish with signs of disease or parasites were used. 


\section{BLOOD SAMPLE COLLECTION AND ANALYSIS}

Blood samples were drawn from the caudal vein using syringes containing the $10 \%$-EDTA. These procedures were carried out within 0.8-1.2 minutes to minimise stress. Determination of red blood cells count (RBC) was performed using Neubauer hemocytometer, following the dilution in a solution of citrate-formol and toluidine blue stain (38 g sodium citrate, $20 \mathrm{~mL}$ formalin $(37 \%), 0.2 \mathrm{~g}$ toluidine blue, $1000 \mathrm{~mL}$ distilled water) as described by Oliveira $e t a l$. (2008). Hematocrit (Hct) was determined by microhematocrit centrifugation and hemoglobin concentration $(\mathrm{Hb})$ by cyanomethemoglobin method. Mean cell volume (MCV) and cell hemoglobin concentration (MCHC) were calculated from the $\mathrm{Ht}, \mathrm{Hb}$ and $\mathrm{RBC}$. Blood smears were stained with a combination of May Grünvald-Giemsa-Wright (Tavares-Dias and Moraes, 2003) and used for counting total and differential total leukocytes and total thrombocyte (Tavares-Dias and Moraes, 2006a; 2007). Differential WBC counts were performed by identifying $200 \mathrm{WBC}$ in each blood smears.

\section{RESULTS}

Dissolved oxygen concentration $(5.4 \pm 1.1 \mathrm{mg} / \mathrm{L})$, temperature $\left(28 \pm 2.0^{\circ} \mathrm{C}\right), \mathrm{pH}(7.2 \pm 0.9)$ and electric conductivity $(115.6 \pm 2.2 \mu \mathrm{S} / \mathrm{cm})$ did not show any statistical difference throughout the experiment. These values were within the limits considered to be suitable for production performance and health maintenance of tropical fish (Kubitza, 2003).

Table 1 - Red blood cell parameters of $B$. amazonicus $(\mathrm{N}=25)$ farmed in pond. Mean \pm standard deviation (SD).

\begin{tabular}{lll}
\hline Parameters & Mean \pm SD & Minimum-Maximum \\
\hline Red blood cells count $\left(\times 10^{6} / \mu \mathrm{L}\right)$ & $1.27 \pm 0.19$ & $1.13-1.56$ \\
\hline Hemoglobin $(\mathrm{g} / \mathrm{dL})$ & $6.6 \pm 0.6$ & $5.5-8.1$ \\
\hline Hematocrit $(\%)$ & $28.0 \pm 3.3$ & $23.0-35.0$ \\
\hline MVC (fL) & $220.0 \pm 16.4$ & $191.7-253.8$ \\
\hline MCHC $(\mathrm{g} / \mathrm{dL})$ & $24.0 \pm 16.4$ & $17.0-30.7$ \\
\hline
\end{tabular}

The mean values and the ranges of the red blood cells parameters for B. amazonicus are shown in Table 1. The $\mathrm{MCV}$ and $\mathrm{MCHC}$ are the parameters with higher variation in this species.

Lymphocytes (Fig. 1), monocytes (Fig. 2), thrombocytes (Fig. 3), neutrophils and heterophils (Fig. 4) were found in $B$. amazonicus. They presented similar morphological features to leukocytes reported by Tavares-Dias et al. (1999), for the same species, except heterophils, which was not identified by those authors. Heterophils are large and round cells, containing eosinophilic and basophilic granules randomly distributed in the cytoplasm, and the amount of granules depending on the degree of cell maturation. The few mature cells had most eosinophilic granules and a few basophilic granules. However, the total amount of eosinophilic and basophilic granules seems to increase during the maturation of the heterophil (Fig. 4-6).

Total thrombocyte counts varied from 12,870 to 54,990 $\mu \mathrm{L}$ and total leukocyte counts from 3,900 to $8,520 \mu \mathrm{L}$. Neutrophils and heterophils were the granulocytes found in B. amazonicus (Table 2).

Table 2 - Total thrombocytes and leukocytes counts of $B$. amazonicus $(\mathrm{N}=25)$ farmed in pond. Mean \pm standard deviation (SD)

\begin{tabular}{llc}
\hline Parameters & Mean \pm SD & Minimum-Maximum \\
\hline Thrombocytes $(\mu \mathrm{L})$ & $30,692 \pm 11,633$ & $12,870-54,990$ \\
\hline Leukocytes $(\mu \mathrm{L})$ & $13,324 \pm 7677$ & $3900-28,520$ \\
\hline Lymphocytes $(\mu \mathrm{L})$ & $5680 \pm 4001$ & $468-12,512$ \\
\hline Lymphocytes $(\%)$ & $38.9 \pm 16.3$ & $12.0-63.0$ \\
\hline Monocytes $(\mu \mathrm{L})$ & $2156 \pm 2487$ & $317-8556$ \\
\hline Monocytes $(\%)$ & $13.9 \pm 7.9$ & $2.0-30.0$ \\
\hline Heterophils $(\mu \mathrm{L})$ & $2117 \pm 1690$ & $62.5-57040$ \\
\hline Heterophils $(\%)$ & $16.3 \pm 8.6$ & $1.0-40.0$ \\
\hline Neutrophils $(\mu \mathrm{L})$ & $3260 \pm 2652$ & $347-11,844$ \\
\hline Neutrophils $(\%)$ & $30.9 \pm 21.0$ & $2.0-65.0$ \\
\hline
\end{tabular}

Table 3 - Red blood cell parameters for different Bryconinae species from literature. Mean \pm standard deviation (SD)

\begin{tabular}{lllllll}
\hline Species & $\mathrm{RBC}\left(\times 10^{6} / \mu \mathrm{L}\right)$ & $\mathrm{Hb}(\mathrm{g} / \mathrm{dL})$ & $\mathrm{Hct}(\%)$ & $\mathrm{MVC}(\mathrm{fL})$ & $\mathrm{MCHC}(\mathrm{g} / \mathrm{dL})$ & References \\
\hline Adult $B$. insignis & $2.08 \pm 0.27$ & $10.6 \pm 0.1$ & $42.4 \pm 0.5$ & $207.0 \pm 2.2$ & $25.2 \pm 0.2$ & Ranzani-Paiva (1991) \\
Adult B. insignis & $1.78 \pm 0.30$ & $8.0 \pm 0.2$ & $33.5 \pm 0.7$ & $186.0 \pm 2.9$ & $24.2 \pm 0.3$ & Ranzani-Paiva (1991) \\
Fry B. cephalus * & $3.70 \pm 0.80$ & $11.5 \pm 1.1$ & $44.1 \pm 2.6$ & $125.2 \pm 27.7$ & $26.0 \pm 2.1$ & Arévalo and Castellano (2003) \\
Juvenile B. cephalus & $3.80 \pm 0.60$ & $13.7 \pm 2.6$ & $45.0 \pm 4.2$ & $122.3 \pm 15.3$ & $30.6 \pm 5.6$ & Arévalo and Castellano (2003) \\
Adult B. cephalus & $2.80 \pm 0.90$ & $14.5 \pm 1.8$ & $42.2 \pm 5.6$ & $171.9 \pm 73.7$ & $34.9 \pm 4.6$ & Arévalo and Castellano (2003) \\
Young B. orbignyanus & $3.28 \pm 0.48$ & $10.7 \pm 1.3$ & $40.2 \pm 3.1$ & $125.0 \pm 22.0$ & $26.9 \pm 3.9$ & Tavares-Dias and Moraes (2006) \\
Young B. hilarii & $-12.2 \pm 3.7$ & $35.5 \pm 6.4$ & - & $33.9 \pm 4.3$ & Tavares-Dias et al.(2003) \\
Young B. amazonicus & $3.638 \pm 212.1^{*}$ & $12.6 \pm 0.37^{*}$ & $49.1 \pm 1.05^{*}$ & - & & Urbinati and Carneiro (2006) \\
Fry B. amazonicus & $2.91 \pm 0.41$ & $10.9 \pm 1.2$ & $39.0 \pm 8.7$ & $134.8 \pm 24.3$ & $28.8 \pm 4.5$ & Tavares-Dias et al.(1999) \\
Juvenile B. amazonicus & $1.27 \pm 0.99$ & $6.6 \pm 0.6$ & $28.0 \pm 3.3$ & $220.0 \pm 16.4$ & $24.0 \pm 16.4$ & Present study \\
\hline
\end{tabular}

*Standard error of mean 


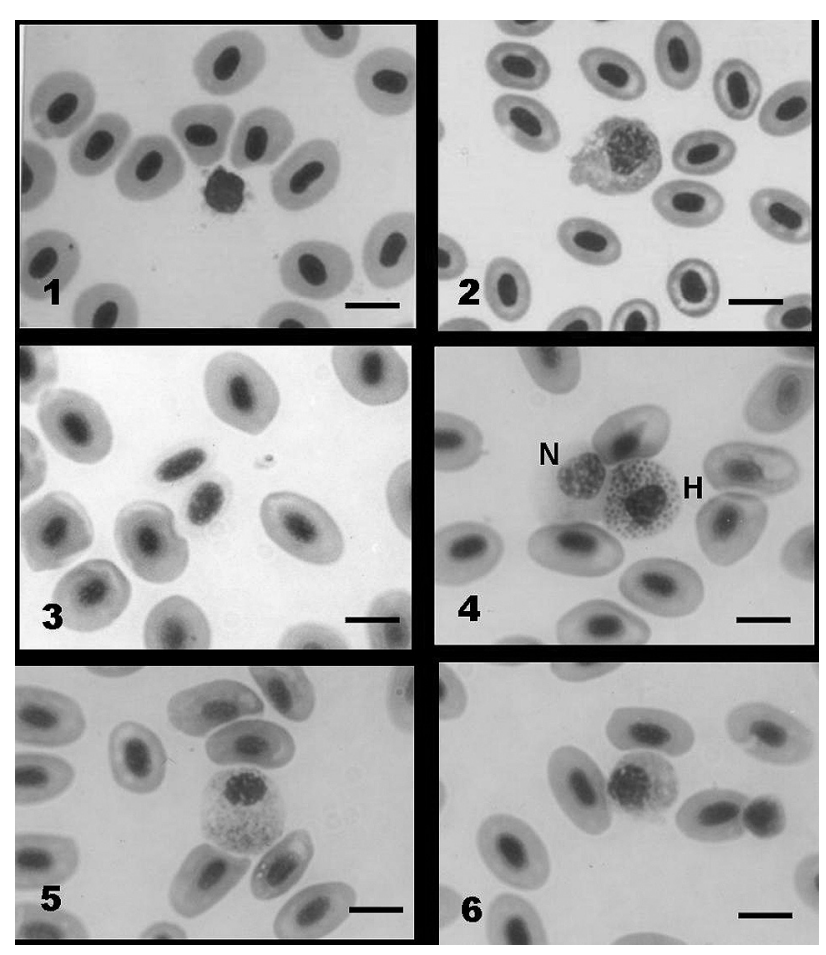

Figures 1-6 - Brycon amazonicus peripheral blood cells stained with May Grünwald-Giemsa-Wright. (1) Lymphocyte, (2) monocyte, (3) fusiform thrombocytes, (4) neutrophil (N) and heterophil with higher account of granules $(\mathbf{H}),(\mathbf{5})$ and $(\mathbf{6})$ heterophil with few granules. Bars $=7.0 \mu \mathrm{m}$.

\section{DISCUSSION}

Hematological parameters of various farmed fish species have been investigated aiming to establish baseline values (Ranzani-Paiva, 1991; Guijarro et al., 2003; Tavares-Dias and Moraes, 2004; Kori-Siakpere et al., 2005; Tavares-Dias and Moraes, 2007), in addition to identify disturbances caused by parasitic infections (Tavares-Dias and Moares, 2004). Interspecies variations in red blood cells parameters have been attribute to many internal and external factors (TavaresDias and Moraes, 2004; Tavares-Dias and Moraes, 2006a) such as the quality of the aquatic environment, season, sex, age, nutritional status, stress due to capture, handling and sampling procedures and water temperature (Ranzani-Paiva, 1991; Guijarro et al., 2003; Tavares-Dias and Moraes, 2004; Kori-Siakpere et al., 2005). Thus, for B. amazonicus juvenile, red blood cell counts, hematocrit and hemoglobin values were lower than for fry B. amazonicus and for other Bryconinae species, yet, MCV was higher than for these fish (Table 3). Additionally, these two $B$. amazonicus populations came from different habitats, probably explaining the difference in these parameters (Guijarro et al., 2003; Tavares-Dias and Moraes, 2004).

A characteristic feature of fish is the wide physiological range of blood parameters and also the great individual variation (Tavares-Dias et al., 2003; Kori-Siakpere et al., 2005; Tavares-Dias and Moraes, 2007), which has been attributed to factors such as genetic variation, nutritional status, sex, age, stress due to capture, handling and sampling procedures (Tavares-Dias and Moraes, 2004; Kori-Siakpere et al., 2005). In B. amazonicus from the present study, among red blood cell parameters, the red blood cell counts, hemoglobin concentration and hematocrit have lower intraspecific variation. Similar findings were reported for $B$. orbignyanus (Tavares-Dias and Moraes, 2006a) and B. insignis (Ranzani-Paiva, 1991). However, for $B$. hilarii, the variation of hemoglobin, hematocrit and MCHC was low, due to the few samples used.

Mechanisms of specific immunity in fish, similarly to lower vertebrates, are significantly less developed and play markedly less important role than in birds or mammals (Stosik et al., 2001; Tavares-Dias et al., 2007). In contrast, fish have non-specific resistance system, which plays the basic role in the organism defense against pathogenic and environmental factors (Stosik et al., 2001; Passantino et al., 2005). Piscine

Table 4 - Differential leukocyte counts for Bryconinae species from literature.

\begin{tabular}{|c|c|c|c|c|c|c|c|}
\hline Species & Lymph (\%) & Mon (\%) & Neutr (\%) & Heter. (\%) & CGE (\%) & Eos. (\%) & References \\
\hline Brycon insignis & $0-8.0$ & $0-81.0$ & $8.0-93.0$ & & $0.0-40.0$ & $0.0-0.0$ & Ranzani-Paiva (1991) \\
\hline Fry $B$. cephalus & 84.1 & 1.9 & 6.7 & 7.0 & & & Arévalo and Castellano(2003) \\
\hline Juvenile $B$. cephalus & 46.5 & 1.4 & 25.8 & 25.2 & & $\overline{0.5}$ & Arévalo and Castellano(2003) \\
\hline Adult $B$. cephalus & 53.2 & 0.9 & 21.8 & 28.3 & 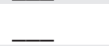 & 0.5 & Arévalo and Castellano(2003) \\
\hline Young B. orbignyanus & 15.5 & 6.3 & 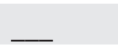 & $78.1^{\star}$ & $\overline{-}$ & 0.0 & Tavares-Dias and Moraes (2006) \\
\hline Juvenile $B$. amazonicus & 51.5 & 13.7 & 24.1 & & $\overline{10.7}$ & & Tavares-Dias et al.(1999) \\
\hline Juvenile $B$. amazonicus & 55.5 & 9.0 & - & $34.6 *$ & - & 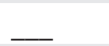 & Affonso et al.(2007) \\
\hline Juvenile $B$. amazonicus & 38.9 & 13.9 & $\overline{30.9}$ & 16.3 & & & Present study \\
\hline
\end{tabular}

Lymph= Lymphocytes; Mon- Monocytes; Neut= Neutrophils; S.G.E. = Special granulocytic cells; Eos= Eosinophils. *Neutrophils and heterophils were counted together 
thrombocytes represent a link between innate and adaptive immunity (Passantino et al., 2005). Therefore, piscine thrombocytes function is not limited to aggregation, but also may involve a great potential for phagocytosis (Kolman et al., 2003; Tavares-Dias and Moraes, 2004; Tavares Dias et al., 2007). In juveniles $B$. amazonicus there was intraspecific variation in total thrombocyte counts, and the values were similar to those in young B. orbignyanus (Tavares-Dias and Moraes, 2006a), due to the same counting method used.

Piscine leukocytes, particularly granulocytes, have been controversial (Tavares-Dias et al., 2003; Tavares-Dias and Barcellos, 2005; Tavares-Dias, 2006b; Tavares-Dias and Moraes, 2007). Several species have blood neutrophils and others have only heterophils, while in a few fishes, both neutrophils and heterophils are present (Tavares-Dias and Moraes, 2004; Tavares-Dias and Barcellos, 2005; Tavares-Dias, 2006; Tavares-Dias and Moraes, 2006a, b). The B. amazonicus, as well as other Bryconinae from literature (B. orbignyanus and B. cephalus) had neutrophils and heterophils (Table 4). On the other hand, studies in B. amazonicus (Carneiro et al., 2002) and B. hilarii (Tavares-Dias et al., 2003) did not report the presence of heterophils, but only neutrophils. However, in present study, $B$. amazonicus neutrophils had typical granules while heterophils had eosinophilic-basophilic granules.

Fish heterophil have a variable staining of granules, which seem to depend on the species and/or cell maturity (TavaresDias and Barcellos, 2005; Tavares-Dias and Moraes, 2006b), and this fact has been also observed here in B. amazonicus. In $B$. amazonicus, mature heterophil granules were identical to farmed B. orbignyanus described by Tavares-Dias and Moraes (2006b). However, it has been reported that in B. orbignyanus (Tavares-Dias and Moraes, 2006b), mature heterophil granules have few similarity to Hoplosternum litoralle (Tavares-Dias and Barcellos, 2005), but in both species the heterophils showed both eosinophilic and basophilic properties. Thus, it is easy to believe that the eosinophils reported for $B$. hilarii (TavaresDias et al., 2003) and for B. cephalus (Arévalo and Castellano, 2003) may be immature heterophils, which presents few basophilic granules, as found here to $B$. amazonicus.

Fish leukocytes are involved in non-specific defense mechanisms (Tavares-Dias and Moraes, 2004; TavaresDias and Moraes, 2007; Pavlidis et al., 2007). Monocytes/ macrophages and lymphocytes are involved in the immune response leading to the production of antibodies. Neutrophils are effector key cells in non-specific immunity, as they migrate into the infection site, to recognize, ingest and destroy many pathogens (Tavares-Dias and Moraes, 2004; Tavares-Dias, 2006; Tavares-Dias and Moraes, 2007; Pavlidis et al., 2007). Heterophils and neutrophils have similar functions, but different morphological features (Tavares-Dias and Moraes, 2004). Total leukocyte counts for $B$. amazonicus juveniles obtained here $(13,324 \pm 7677 \mu \mathrm{L})$ were smaller than for young B. orbignyanus $(23,290 \pm 7041 \mu \mathrm{L})$ (Tavares-Dias and Moraes, 2006a), although has been used similar method for counting WBC, hence this indicates an interspecific variation. However, total leukocyte counts for $B$. amazonicus juveniles was higher than for juvenile $B$. amazonicus fed with a diet without complementary vitamin $\mathrm{C}$ (Abreu and Urbinati, 2006), because a different method of count was used. Matrinxã $B$. amazonicus differential leukocytes count has shown few variations in relative number when compared to some Bryconinae species from literature (Table 4). Differences in the WBC counts may be attributed to many factors, both biotic (such as age, season, maturity, pathogens) and abiotic (including water temperature, $\mathrm{pH}$, dissolved oxygen content, sex or maturity stage) and in particular to stress (Tavares-Dias and Moraes, 2004; Tavares-Dias and Moraes, 2007; Pavlidis et al., 2007). Therefore, the differences demonstrated in this study may be related to species, nutritional differences, and sex or maturity stage.

In $B$. orbignyanus (Tavares-Dias, 2006a, b), as well as in $B$. amazonicus of present study, no special granulocytic cell was found. Nevertheless, neutrophils extremely fine granules were found following staining with May Grünvald-Giemsa-Wright stain. Therefore, the misidentification of special granulocytic cell in B. amazonicus and B. hilarii from literature (Table 4) can be due to failure in staining procedures of blood smears with May Grünvald-Giemsa stain, which makes a difficult cellular identification in some fish species. However, May Grünvald-Giemsa-Wright stain allows easy recognition of heterophils and neutrophils. Other authors, for example, Tavares-Dias and Barcellos (2005) and Pavlidis et al. (2007), have also discussed misidentification founds resulting from the use of the May Grünvald-Giemsa stain.

In summary, for $B$. amazonicus juvenile, red blood cell counts, hematocrit and hemoglobin have presented differences when compared to B. amazonicus and other Bryconinae species from literature, which were discussed here. WBC parameters reported in this work suggests that the presence of granulocytes, neutrophil and heterophil, are characteristic to the Bryconinae species. These findings corroborate with the hypothesis from Pavlidis et al. (2007), who stated that blood parameters studies might be used to determine the systematic relationship among certain fish species. Furthermore, leukocytes are the primary line of immunological defense, and in healthy B. amazonicus, lymphocytes and neutrophils were typically the most prevalent circulating leukocytes and therefore, these two granulocytes constitute the primary barrier of the immune system for this species. Hence, this immune function might be reflected by the lymphocytes and neutrophils counts, and then a lower number of these cells might result in a less efficient functioning of the immune 
system in $B$. amazonicus. However, further functional studies are necessary to better understand the participation of these granulocytes in immune system of this Bryconinae species, as well as to indicate any deviation caused by disturbances in their physiology. Blood parameters can be an important tool to measure the health status of $B$. amazonicus bred in intensive culture, assessing the effects of stress that can cause to parasitic infections in the population.

\section{ACKNOWLEDGMENTS}

The authors gratefully acknowledge the research grants provided by FAPEAM (Fundação de Amparo à Pesquisa do Estado do Amazonas, \#2203/05 and \# 2204/05), and CNPq (Conselho Nacional de Desenvolvimento Científico e Tecnológico, \#35.0117/20005-5).

\section{LITERATURE CITED}

Abreu, J.S.; Urbinati, E.C. 2006. Physiological responses of matrinxã Brycon amazonicus fed different levels of vitamin $\mathrm{C}$ and submitted to air exposure. Acta Amazonica, 36: 519-524.

Affonso, E.G.; Silva, E.C.; Tavares-Dias, M.; Menezes, G.C.; Carvalho, C.S.M.; Nunes, E.S.S.; Itaiassú, D.R.; Roubach, R.; Ono, E.A.; Fim, J.D.I.; Marcon, J.L. 2007. Effect of high levels of dietary vitamin on the blood responses of matrinxã (Brycon amazonicus). Comparative Biochemistry Physiology, Part A, 147: 383-388.

Arévalo, M.B.B.G.H.; Castellano, J.A. 2003. Hematology and sanguine chemistry of yamú Brycon siebenthalae. In. WORD AQUACULTURE 2003, Salvador, BA. Anais. Salvador Word Aquaculture Society, p. 50.

Carneiro, P.C.F; Urbinati, E.C.;And Martins, M.L. 2002. Transport with different benzocaine concentrations and its consequences on hematological parameters and gill parasite populations of matrinxã Brycon cephalus (Günther, 1869) (Osteichthyes, Characidae). Acta Scientiarum, 24: 555-560.

Guijarro, A.I.; Lopez-Patiño, M.A.; Pinillos, M.L.; Isorna, E.; De Pedro, N.; Alonso-Gómez, A.L.; Alonso-Debate, M.; Delgado, M.j. 2003. Seasonal changes in haematology and metabolic resource in the tench. Journal of Fish Biology, 62: 803-815.

Kolman, H.; Terech-Majwwaska, E.; Kolman, R.; Szarek, J.; Swiatecki, A. 2003. The ingestion of Aeromonas salmonicida by fish blood phagocytes in vitro under influence of herbicides. Acta Piscaria, 2: 123-130.

Kori-Siakpere, O.; Ake, J.E.G; Idoge, E. 2005. Haematological characteristics of the African snakehead, Parachanna obscura. African Journal of Biotecnology, 4: 527-530.

Kubitza, F., 2003. Qualidade da água no cultivo de peixes e camarôes. Jundiaí, SP. 229p.

Lima, F. C. T. 2003. Subfamily Bryconinae (Characins, Tetras). In: Reis, R.E; Kulander, S. O; Ferraris Jr, C. J. (Orgs.) Check List of the Freshwater Fishes of South and Central America. EDPURCS, Porto Alegre: p.174-181.
Oliveira-Junior, A.A; Tavares-Dias, M.; Marcon, J.L. 2008. Biochemical and hematological reference ranges for Amazon freshwater turtle, Podocnemis expansa (Reptilia: Pelomedusidae), with morphologic assessment of blood cells. Research in Veterinary Science, in press.

Passantino, L.; Cianciotta, A.; Patruno, R.; Ribaud, M.R.; Jirillo, E.; Passantino, G.F. 2005. Do fish thombocytes play an immunological role? Their cytoenzimatic profiles and fuction during an accidental piscine candidiasis in aquarium. Immunopharmacology and. Immunotoxicology, 27: 345-356.

Pavlidis, M.; Futter, W.C.; Kathario, P.; Divanach, P. 2007. Blood cells of six Mediterranean mariculture fish species. Journal of Applied Ichthyology, 23: 70-73.

Ranzani-Paiva, M.J.T. 1991. Características sangüíneas da pirapitinga do sul, Brycon sp., sob condições experimentais de criação intensiva. Brazilizan Journal of Veterinary Research and Animal Science, 28: 141-153.

Ranzani-Paiva, M.J.T. 1996. Células sangüíneas e contagem diferencial de leucócitos em pirapitinga do sul, Brycon sp., sob condiçôes experimentais de criação intensiva. Revista Ceres 43: 685-696.

Stosik, H.; Deptula, W; Travnicek, M. 2001. Studies on the number and ingesting ability of thrombocytes in sick carps (Cyprinus carpio). Veterinary Medicine 46: 12-16.

Tavares-Dias, M. 2006. A morphological and cytochemical study of erythrocytes, thrombocytes and leukocytes in four freshwater teleosts. Journal of Fish Biology 68: 1822-1833.

Tavares-Dias, M.; Moraes FR. 2003. Características hematológicas da Tilapia rendalli Boulenger, 1896 (Osteichthyes: Cichlidae) capturada em "Pesque-Pague" de Franca, São Paulo, Brasil. Bioscience Journal, 19: 103-110.

Tavares-Dias, M.; Moraes, F.R. 2004. Hematologia de peixes teleósteos. Ribeirão Preto, São Paulo: Villimpress.

Tavares-Dias M.; Barcellos J.F.M. 2005. Peripheral blood cells of the armored catfish Hoplosternum littorale Hancock, 1828: a morphological and cytochemistry study. Brazilian Journal of Morphologic Science, 22: 215-220.

Tavares-Dias, M.; Moraes, F.R. 2006a. Hematological parameters for the Brycon orbignyanus Valenciennes, 1850 (Osteichthyes: Characidae) intensively bred. Hidrobiológica, 16: 271-274.

Tavares-Dias, M.; Moraes, F.R. 2006b. Morphological, cytochemical, and ultrastructural study of thrombocytes and leukocytes in neotropical fish, Brycon orbignyanus Valenciennes, 1850 (Characidae, Byconinae). Jounal of Submicroscopic Cytology and Pathology, 38: 209-215.

Tavares-Dias, M.; Moraes, F. R. 2007. Leukocyte and thrombocyte reference values for channel catfish (Ictalurus punctatus Raf.), with an assessment of morphological, cytochemical, and ultrastructural features. Veterinary Clinical Pathology, 36: 49-54.

Tavares-Dias, M.; Frascá-Scorvo, C. M.D.; Moraes, F.R.; CamposFilho, E. 1999. Características hematológicas de teleósteos brasileiros. IV. Parâmetros eritroleucométricos, trombométricos e glicemia do matrinxã Brycon cephalus Günther, 1869 (Osteichthyes:Characidae). Ars Veterinaria 15: 149-153. 


\section{ACTA}

Tavares-Dias, M.; Schalch, S.E.C.; Moraes, F.R. 2003. Hematological characteristics of Brazilian teleosts. VII. Parameters of seven species collected in Guariba, São Paulo State, Brazil. Boletim do Instituo de Pesca, São Paulo, 29: 109-115.

Tavares-Dias, M.; Ono, E. A.; Pilarski, F; Moraes, F. R. 2007. Can thrombocytes participate in the removal of cellular debris in the circulating blood of teleost fish? A cytochemical study and ultrastructural analysis. Journal of Applied Ichthyology, 23: 709-712.

Urbinati, E.C.; Carneiro, P.C.F. 2006. Sodium chloride added to transport water and physiological responses of matrinxã Brycon amazonicus (Teleost: Characidae). Acta Amazonica, 36: 569-572.

Recebido em 22/12/2007

Aceito em 14/08/2008 
